\title{
Domestic Judicial Treatment of European Court of Human Rights Case Law - príběh o kabátu, který naše soudy nosí dál než košili
}

\section{Domestic Judicial Treatment of European Court of Human Rights Case Law - Near Is My Shirt, but Nearer Is My Skin}

\author{
Martin $\mathrm{Kopa}^{*}$
}

\begin{abstract}
Abstrakt
Tento článek nabizi kontextuálni kritické postréby prì čteni kniby Domestic Judicial Treatment of European Court of Human Rights Case Law: Beyond Compliance (KOSAŘ, D. et al. Routledge, 2020) spresaby do současných diskuzi oblednè legitimity judikatury Evropskébo soudu pro lidskáa práva. Autor vychází ze své osobni žušenosti s fungováním Evropského soudu pro lidská práva, Nejuyššího správního soudu a Ústavního soudu a konfrontuje své postreby se zjištènimi kniby. Poukazuje na slabši momenty knihy, pridává svá pozorováni a také návrby na dalši výzkum, který by se mobl zaměrit zejména na práci s judikaturou Evropskébo soudu pro lidská práva ze strany nižšich soudì.
\end{abstract}

Klíčová slova

Evropský soud pro lidská práva; Nejvyšši soud; Nejuyšsí správní soud; Ústavní soud; compliance.

\section{Abstract}

This article offers a critical contextual reading of the book. Domestic Judicial Treatment of the European Court of Human Rights Case Law: Beyond Compliance (KOSAR, D. et al., Routledge, 2020) on the background of current discussions about the legitimacy of the European Court of Human Rights case law. The author draws on his personal experience with the functioning of the European Court of Human Rights, the Czech Supreme Administrative Court and the Czech Constitutional Court when confronting his observations with the book's findings. He points out the weaker moments of the book, adds his situated observations, and suggests possible further research avenues, among which the focus on the lower courts' use of the European Court of Human Rights case law stands out.

Keywords

The European Court of Human Rights; the Czech Supreme Court; the Czech Supreme Administrative Court; the Czech Constitutional Court; Compliance.

JUDr. Martin Kopa, Ph.D., soudce, Krajský soud v Brně / Judge, Regional Court in Brno, Czech Republic / E-mail: mkopa@ksoud.brn.justice.cz

Dř́ve působil u Evropského soudu pro lidská práva, Ústavního soudu a Nejvyššího správního soudu, na něž se před nástupem do soudcovské funkce obracel i jako advokát. 


\section{Úvod}

V knize, o níž bude tato krátká reflexe, vystupuje několik postav. Nejprve je to Evropský soud pro lidská práva, jeho judikatura a samotná Úmluva o ochraně lidských práv a základních svobod. Bez nich bychom celý evropský prúběh základních práv odvyprávět nemohli. Právě nyní to považuji za velmi důležité zmínit. $V$ době, ve které ochrana základních práv kvưli pandemii koronaviru prošla zatěžkávací zkouškou, Úmluva totiž oslavila 70 let. Jak na konferenci u prŕležitosti tohoto výročí upozornil současný předseda štrasburského soudu Robert Spano: „Polarizace, rozdělení společnosti a výży sowvisejicí s pandemii predstavuji záva žnou broz̧bu pro základní principy Rady Evropy a Úmluvy. Rámec práv

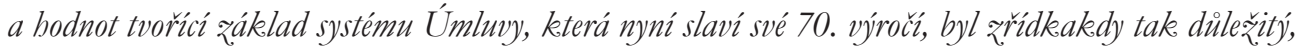
jako je tomu ted", právěv v tento moment."1

Hlavní roli v reflektované knize ${ }^{2}$ však hraje někdo jiný. Trojice našich vrcholných soudů: Ústavní soud, Nejvyšší správní soud a Nejvyšší soud. Leitmotivem celého prúběhu je chování těchto českých postav vǔči postavám ze Štrasburku. Jak spolu vycházejî̉ Bere se v české justici ohled na to, s čím přicházejí štrasburští hrdinové? Jsou vůbec vítaní? Nebo je česká pohostinnost vưči všemu evropskému až přehnaně vstř́ícná? To vše se čtenárii při otevírání knihy honí hlavou. Trochu prìitom tuší, že každý z našich vysokých soudů bude s ohledem na svůj věk, agendu a institucionální historii vystupovat jinak než jeho dva souputníci.

Jako člověk, který se osobně zná se třemi ze čtyř soudních postav prúběhu této knihy (výjimkou je NS), se pokusím její prǐ̉běh na následujících rádcích reflektovat. Ke každé z relevantních kapitol pripojím své postřehy, které mě při čtení napadly. $V$ části 4 této reflexe se pak zaměřím na ÚS, se kterým jsem strávil nejvíc času. Moc mě proto zajímalo, co autoři knihy zjistili o jeho práci s judikaturou Soudu, jak milovníci štrasburské judikatury tradičně označuji Evropský soud pro lidská práva.

Ještě než se do toho pustím, dlužím vám jedno vysvětlení. Možná se ptáte, o čem to mluvím v názvu tohoto př́spěvku. Proč kabát, který naše soudy nosí dál než košili? Dalo by tak shrnout mé asi nejsilněǰši očekávání, které jsem od knihy měl. Vlastně jsem se bál jedné věci - že se ukáže, že vysoké soudy s Úmluvou zase tolik nepracují. Na ÚS i NSS jsem slýchával rčení: „Košile blì̌̌šr než kabát." Místo Úmluvy coby kabátu se jako košile aplikovala spíše Listina. Nebo judikatura našich soudů, která ríká to, co „v originále“ zní ze Štrasburku. Minimálně o správním soudnictví pak mohu říci, že v něm naše soudy oblékají ještě Listinu základních práv EU coby - abychom zachovali započatou metaforu - lyžă̌rskou bundu, ve které sjiždí svahy unijního práva. Říkal jsem si, že judikatura Soudu proto jako štrasburský kabát, který si naše soudy berou, pokud je opravdu zima, většinou zůstává ve skříni. A napjatě jsem očekával, jestli i $\mathrm{k}$ tomuto tématu $\mathrm{v}$ knize objevím zajímavá data.

1 Bliže viz s. 3 přepisu jeho projevu. Dostupné z: https://bit.ly/3oKuQNN

2 KOSAǨ, David et al. Domestic Judicial Treatment of European Court of Human Rights Case Law: Beyond Compliance. London: Routledge, 2020. 


\section{Proč je vůbec důležité pochopit, jak vnitrostátní soudy zacházejí se štrasburskou judikaturou?}

Autoři v úvodu přichází s mnoha varováními. Vzestup populismu ve východní, ale i západní Evropě se totiž opírá o hodnoty, které odporují základním principům Úmluvy. Bohužel je třeba s autory souhlasit, že ne všem zemím Rady Evropy lze přiřadit štítek liberální demokracie. Vlna demokratického backslidingu v zemích Rady Evropy pak podle autorů zesiluje potřebu účinné kontroly. ${ }^{3}$

Rád bych se ovšem blíže zaměřil na jeden faktor, nad kterým jsem přemýšlel při čtení úvodní kapitoly knihy. Přemýšlím nad ním v posledních letech často. Jde o debatu, která se odehrává dlouhodobě ve Spojených státech. I v Evropě se ovšem víc a víc objevuje otázka, zda se to s tzv. evolutivním výkladem Úmluvy, podle kterého by se Úmluva měla vykládat ve světle dnešních okolností a podmínek, a nikoli podle toho, co zamýšleli zástupci smluvních stran při sepisování Úmluvy, trochu už nepřehání. Originalismus ve Štrasburku ani nedostal šanci. ${ }^{4}$ Přesto se ozývají varovné hlasy, které upozorňují, že Soud za použití doktríny, podle níž je Úmluva živoucím instrumentem, nachází v jejím obsahu nová základní práva, na která text Úmluvy nepamatuje nebo dokonce podle jejich tvůrců ani pamatovat neměl. Tento př́stup - a zejména zesilující důraz na textualismus, pokud nejde přímo o prríznivce originalismu - má víc a víc zastánců nejen v USA, ale i v Evropě a v ČR.

Jako jeden prríklad za všechny lze odkázat na slova bývalého soudce Nejvyššího soudu Spojeného království, obávaného barristera, ale také oxfordského historika Lorda Jonathana Sumptiona. Loni přednášel v prestižní sérii BBC Reith Lectures na téma vztahu politiky a práva. ${ }^{5}$ A zejména jeho přednáška s názvem „Human Rights and Wrongs“ se dotýká právě problému judikatorně se rozšiřující působnosti Úmluvy. Lord Sumption v této přednášce říká: „Nemám problém s tím, aby mezinárodni soud piisobil jako vnèjš́ kontrola. Ale vétšina práv, keterá štrasburský soud pridal do našeho práva, je [...] sporná a má velmi daleko k práviom základním. [...] Mnoho lidí bude mit pocit, že by mèla existovat alespon některá z dalšich práv, která vymyslel strasburský soud. Myslim si to sám. Skutečnou otázkou vǐak je, zda by o jejich vytvoreni mèli rozhodovat soudci. Ti existuji, aby aplikovali právo. Je vécí občanu a jejich zástupců, aby roz̧hodli, co má právem být. [...] Hlavnim problémem v oblasti lidských práv je, že [...] prílis snadno transformuje kontroverz̨ni politické otázky na právni otázky pro soudy. Timto zpisobem vylucuje kriticky dỉležité roz̧hodování z.politického procesu. Jelikožje tento proces jedinou metodou, kterou se obyvatelstvo jako celek mưž zapojit, i když neprimo, do formováni práva, je to, myslím, problém.

3 KOSAŘ, 2020, op. cit., s. 1-3.

4 Posledním, kdo se pokoušel takto ve Štrasburku argumentovat, byl zřejmě britský soudce Fitzmaurice na počátku roku 1975, ale jeho argument, že čl. 6 Úmluvy nezaručuje právo na př́stup k soudu, neuspěl. Viz jeho disent k rozsudku ze dne 21. 2. 1975, ve věci Golder proti Spojenému království, č. 4451/70, J 2 a $\int 18-48$. Dostupné z: https://bit.ly/3kRFMXu

5 V̌̌echny jsou dostupné z: https://bbc.in/3oFnScK 
Pokud se budeme zabývat základnimi lidskými právy zpuisobem, který má radikálni důsledky tohoto drubu, pak musime mít velmi jasnou predstavu o tom, co to základni lidské právo ve skutečnosti je. Zejména musime rozlišrovat qákladni lidské právo od něčeho, co je pouzue dobrým nápadem."

Vyloučení některých otázek z politického rozhodování, k čemuž dochází jejich „zlidskoprávněním“, proto vede k sílící kritice, že soudní zakotvení některých lidskoprávních nároků postrádá potřebnou demokratickou legitimitu. Zpochybňuje se tím systém novelizací Úmluvy prostřednictvím sjednávání, ratifikací a podpisů jednotlivých protokolů. To vše může vést k názorovým střetům, odmítání nebo sníženému respektu ke štrasburské judikatuře.

Z druhé strany by odmítání evolutivního výkladu Úmluvy mohlo vést $\mathrm{k}$ postupné ztrátě „kontaktu Úmluvy s realitou“. Proces jejích změn je těžkopádný a neumožňuje v potřebné míře reagovat na změny ve společnosti (byt' i tato těžkopádnost má svoji důležitou demokratickou hodnotu). Jak v reakci na Lorda Sumptiona uvedl v debatě s ním Robert Spano: „politika ze své podstaty nezajištuje individuálni spravedlnost. Politika neumožnuje strízlivý a zásadový rozhodovaci proces, který jemně vyvažuje často neslučitelné a protichuidné hodnoty, keteré nevyhnutelnè vstupuji do hry v individuálnè proživaných událostech. [...] $V$ demokratické společnosti jsou to však nezávisli a nestranni soudci, keteři jsou povéreni k tomu, aby vykládali práva a hodnoty, o néž jde v konkrétnich sporech mezi státem a jeho občany nebo dokonce soukromými osobami nav zájem, keteré vyplývaji z rożmaru či tragédii každodenního života. "7

Co je ve hře? Nic menšího než důvěra veřejnosti v justici či konkrétněji v Soud. Střet mezi dvěma uvedenými názorovými proudy se bude nepochybně v prřístích letech nadále odehrávat a zesilovat. I mezi soudci v jejich judikatuře. Bude vyvolávat nemalé kontroverze. Jednu už vlastně můžeme pozorovat na pozadí případu, o němž nyní rozhoduje plénum ÚS pod sp. zn. Pl. ÚS 2/20. Jde o otázku, zda lze změnu pohlaví podmiňovat chirurgickým zákrokem při současném znemožnění reprodukční funkce a přeměně pohlavních orgánů. Judikatura Soudu dává jasnou odpověd' - nelze. ${ }^{8}$ NSS přesto odmítl judikaturu Soudu následovat v obavách, že by tento názor česká veřejnost nepřijala. V řízení o ústavní stížnosti NSS dokonce výslovně uvedl, že „rozsudek ve věci A. P., Garçon a Nicot je projevem prílišných ambici ESLP a jde o snabu vnutit všem smluvním státuim takové pojetí poblaví, keteré v radě z nich je či postupně začiná být akceptováno, v jüných v̌̌ak narazí na výrazné

6 Viz přepis přednášky Lorda Sumptiona s názvem Human Rights and Wrongs, s. 4-5. Dostupné z: https:// bbc.in $/ 3 \mathrm{mK} 5 \mathrm{cXo}$

7 Srov. přepis přednášky Roberta Spana reagujícího na Reith Lectures Lorda Sumptiona, s. 17. Dostupné z: https://bit.ly/3ee7aMK

8 Viz rozsudek Evropského soudu pro lidská práva ze dne 6. 4. 2017, ve věci A. P., Garçon a Nicot proti Francii, č. 79885/12, 52471/13 a 52596/13; z poslední doby pak viz na věc $A$. P., Garçon a Nicot navazující rozsudek ze dne 19. 1. 2021, ve věci $X$. a Y.proti Rumunsku, č. 2145/16 a 20607/16.

9 Srov. rozsudek NSS ze dne 30. 5. 2019, č. j. 2 As 199/2018-37. 
společenské nepochopení. Judikatura prosazujici prekeotné rozvolnèní parametrů rádu, který je v radě státu vnimán jako prírozený, pritom mư̌̌e vést k silicimu politickému odmitáni koncepce lidských práv."10

Posouzení dané konkrétní věci na ÚS bude mít podle mě významný dopad na to, jak naše soudy budou ke štrasburské judikatuře přistupovat. Byt' osobně nepovažuji výše citovaný rozsudek NSS za př́klad povedeného justičního dialogu (nejsem si totiž při jeho čtení jistý, kdo komu co vnucuje), je třeba vyjít z důležitého předpokladu, na němž staví i autoři reflektované knihy: jsou to právě vnitrostátní soudy, na kterých v prvé řadě závisí funkčnost a účinnost Úmluvy. Proto Soud potřebuje vnitrostátní soudy jako spojence, kteři zajistí jeho důvěryhodnost a společenské uznání. Díky tomu budou moci účinně šírit jeho judikaturu. Z toho důvodu si tento vztah zasluhuje vědecké zkoumání, o němž je celá kniha.

\section{Koncept soudního zacházení se štrasburskou judikaturou a proč (jen) Česko?}

Autoři čtenářům představují pečlivě promyšlený koncept „soudního zacházení s judikaturou“. Cílem má být nalezení odpovědi na 4 otázky: ${ }^{11}$

1. Jak se v čase měnily vzorce zacházení s judikaturou Soudu u vnitrostátních vrcholných soudů?

2. V jakých př́padech vnitrostátní vrcholné soudy odkazují na judikaturu Soudu?

3. Jaké faktory ovlivňují zacházení se štrasburskou judikaturou u vnitrostátních vrcholných soudi̊?

4. Jsou vnitrostátní vrcholné soudy věrnými spojenci Soudu?

Hledání odpovědí na tyto otázky pak probíhá na třech úrovních. Na makro úrovni autoři vysvětlují, jak měřit frekvenci práce s judikaturou nad rámec pouhého výskytů odkazu na ni. Na meso úrovni zkoumají roli, jakou judikatura Soudu hrála v textu vnitrostátních rozhodnutí. Na mikero úrovni se pak zaměřují na nejvýznamnější případy a faktory ovlivnuující různý př́stup vnitrostátních vrcholných soudů vůči judikatuře Soudu. Toto rozvrstvení výzkumu podle autorů umožňuje sledovat „fasádu dómu soudního zacházeni““ (makro úroveñ), vstup do jeho interiéru (meso úroveñ) a pochopení atmosféry i motivů uvnitř dómu, potřebných pro jeho úspěšnou konstrukci (mikro úroveň). Byl jsem zvědav zejména na to, jak autoři rozeberou ony motivy, které mohou být v praxi všelijaké. ${ }^{2}$ Ale o tom až dále.

Musím pak také přiznat, že jsem před otevřením knihy očekával, že bude komparativnější a zaměří se na více evropských zemí. Proto mě nejprve trochu zklamalo, že vlastně

\footnotetext{
10 Viz usnesení ÚS ze dne ze dne 11. 2. 2020, sp. zn. II. ÚS 2460/19, bod 8.

11 KOSAŘ, 2020, op. cit., s. 4 .

12 Ibid., s. 5.
} 
bude jenom česká. Nicméně autoři poté velmi přesvědčivě vysvětlují, proč je to zajímavá volba. Osudy brněnských vysokých soudů jsou totiž tak jedinečné, že to stojî za to. ÚS i NSS vznikly jako po všech stránkách nové instituce. Každý z těchto soudů pak dostal do vínku velmi specifické personální obsazení. NS jsme naopak tak trochu zdědili z doby před Listopadem včetně jeho personálního obsazení. ${ }^{13}$ A zkoumat, jak se to všechno projevuje v prŕístupu těchto soudů k judikatuře Soudu, zní strašně lákavě. Autoři také pracují s tezí, že Česko je př́kladem „dobrého dodržovatele (good complier)“ Úmluvy, což dokládají celkovými počty rozsudků proti ČR, včetně rozsudků, v nichž Soud shledal porušení Úmluvy. Blíže rozebírají jen rok 2018. ${ }^{14}$ Nicméně judikatura zhruba od roku 2013 vyvolává v člověku pocit, že je to obecně velmi specifické období. Proti České republice totiž mnoho rozsudků nepřichází. V roce 2019 např́klad nepřišel ani jeden. A rozsudek ve věci Tempel proti Ceské republice ${ }^{15}$ přišel (bez zhruba čtvrt roku) dvě léta po posledním jemu předcházejícím rozsudku ve věci Kuklik a ostatní proti Céské republice. ${ }^{16}$ Čekali jsme pak dalších cca 10 měsíců na rozsudek velkého senátu ve věci Vavrička a ostatni proti Ceské republice. ${ }^{17} \mathrm{~K}$ rozhodnutí v senátu pak na začátku roku 2021 stále čekalo 101 věcí, ${ }^{18}$ které štrasburský soud komunikoval vládě a neshledal je tedy (zatím) nepřijatelnými. Což vůbec není málo. Samozřejmě mohu pouze spekulovat, jak všechny tyto nerozhodnuté věci dopadnou. Ale nabízí se otázka, zda Česká republika po jejich rozhodnutí v následujících letech opravdu i nadále bude mít tak dobrou image, kterou jí autoři připisují.

V závěru úvodu pak autoři představují ve zkratce svůj hlavní argument. Zjistili vlastně pět věcí. První z nich je, že většina odkazů na judikaturu Soudu má spíše ornamentální funkci, ač i tato funkce hraje důležitou roli při „zakořenění“ štrasburské judikatury do našeho práva. Autoři na základě dat také dospěli k závěru, že vnitrostátní soudy působí jako šiřitelé norem, kteří často přímo do vlastní judikatury zahrnují principy z judikatury Soudu proti jiným zemím Rady Evropy. Třetím poznatkem je, že přístup všech tři soudů se měnil v čase. Autoři pak překvapivě neodhalili velký rozdíl mezi chováním ÚS a obecnou justicí. Pokud již bylo možné hovořit o rozdílech, lze jej spatřovat mezi NS na jedné straně a ÚS s NSS na straně druhé. Posledním závěrem autorů je, že vnitrostátní soudy jen vzácně zpochybňují legitimitu Soudu. Spíše se chovají jako jeho spojenci.

13 KOSA ̌r, 2020, op. cit., s. 7.

14 Ibid.

15 Viz rozsudek ze dne 25. 6. 2020, ve věci Tempel proti České republice, č. 44151/12.

16 Viz rozsudek ze dne 4. 10. 2018, ve věci Kuklík a ostatní proti České republice, č. 15493/12 a další.

17 Viz rozsudek velkého senátu ze dne 8. 4. 2021, ve věci Vavrička a ostatní proti Céské republice, stížnosti č. 47621/133867/1473094/1419298/1519306/1543883/15.

18 Viz profil České republiky ze stránek Evropského soudu pro lidská práva. Dostupné z: https://bit. ly/3kO17B1 


\section{Design výzkumu}

$\mathrm{Na}$ začátku kapitoly o našich soudech jsem pocit'oval zejména neskonalý obdiv k autorům, protože jejich výzkum musel představovat náročnou mravenčí práci. Nebudu zde jeho podobu do detailu převypravovat. Spíše jen zmíním pár momentů, u kterých jsem se pozastavil. Autoři předpokládají, že pokud soudy používají existující judikaturu, pak ji citují, a tyto odkazy na štrasburskou judikaturu pak naznačují, že soudci mají potřebu zabývat se rozsudky Soudu. ${ }^{19}$

Přiznám se, že mám trochu jinou praktickou zkušenost. Zejména z NSS. Přímo souvisí s oním rčením „košile bližši než kabát", o němž píšu v úvodu. Judikatura Soudu se vlastně materiálně používala, protože šlo o principy z ní plynoucí. Konkrétně si vzpomínám na jednu věc, kde šlo o rovnost zbraní, a v návrhu konceptu rozsudku se proto objevil odkaz na rozsudky Niederöst-Huber proti Šýcarsku ${ }^{20}$ a Brandstetter proti Rakousku. ${ }^{21}$ Senát však vyjádřil přání, jestli bychom tu píseň o požadavku, aby každá ze stran řízení mohla obhajovat svou věc za podmínek, které ji z pohledu řízení jako celku podstatným zpơsobem neznevýhodňují vzhledem k protistraně, nemohli odehrát za pomocí vlastních hudebních nástrojů, tedy judikatury samotného NSS. Byli si jistí, že bychom je našli. A našli. Štrasburskou judikaturu jsme proto nahradili. Soudci tedy brali štrasburskou judikaturu vážně. ${ }^{22}$ Alespoň po materiální stránce. Rádi jí ovšem dávali vlastní fasádu, respektive - abych zachoval onu metaforu - bylo jim dostatečně teplo v košili a kabát nepotřebovali. Jde o formu zacházení se štrasburskou judikaturou, ale hlubší rozklíčování tohoto zacházení by již zřejmě bylo nad lidské vědecké možnosti.

Bylo také podnětné číst, jak si autoři obstarávali data. Musím se s nimi plně ztotožnit, pokud tvrdí, že některé z vyhledávačů našich vysokých soudů nejsou úplně „user-friendly“. Byt' je samožrejmě skvělé, že je vưbec máme, je na Nalusu - vyhledávači ÚS - zkrátka vidět, že je z roku 2006 se vším, co z toho plyne. ${ }^{23}$ Ve vyhledávači NS se také jeho rozhodnutí hledají poměrně bolestivě. A vyhledávač NSS, byt' je nejpovedenější, stále nestačí na vyhledávání skrze funkci „site:“ na Googlu, což vlastně platí pro všechny tři vyhledávací rozhraní. Abych byl ovšem férový, je třeba prriznat, že i HUDOC má své mouchy.

Pro nás méně vzdělané v kódování pak možná stálo za bližší vysvětlení, jak autoři jednotlivá získaná data procesovali. Zejména jsem ztuhl u následující věty, která v originále zněla: ,[...] all obtained documents have been converted to a plain-text format, which allows for a smoother custom processing in the R program. We used a simple BVA (BioVisionAlexandria) program for

19 KOSA ̌r, 2020, op. cit., s. 85.

20 Rozsudek ze dne 18. 2. 1997, ve věci Nideröst-Huber proti Süýcarsku, č. 18990/91, \$ 23.

21 Rozsudek ze dne 28. 8. 1991, ve věci Brandstetter proti Rakousku, č. 11170/84 a další, \66.

22 KOSǍ̌, 2020, op. cit., s. 85.

23 Byt’ se údajně již má připravovat nový vyhledávač judikatury ÚS. 
the conversion. In further pre-processing of the files we removed punctuation and unnecessary white space, and we converted the character encoding to UTF-8, all using the $R$ package tau. "24 Uprímně priznávám, že jsem z ní nepochopil vůbec nic. Proto mi jádro praktické podoby výzkumu zahaluje menší tajemství a otázka, jaká to kouzla vlastně k výsledkům vedla. Ale věrím, že zkušenější čtenáři všemu porozuměli.

Na vážnější notu (ale jen trochu) jsem si pak říkal, jakou roli mohla zejména u NS hrát anonymizace, na níž autoři upozorňují. ${ }^{25}$ Nelze opomínat, že její podoba právě u NS v minulosti nabírala až komických rozměrů. Jejím nejvtipnějším aspektem, který ale mohl mít př́mý dopad na výzkum autorů, byla anonymizace judikatury Soudu, díky které se čtenář nedozvěděl nejen jméno stěžovatele, ale ani států, proti němuž stížnost směřovala. ${ }^{26}$

Tentokrát už ale zcela vážně k meso úrovni celého výzkumu. Na s. 94 autoři vymezují hlavní kategorie, podle kterých kódovali vzorek rozhodnutí na této úrovni. Nejprve se zajímají o to, jak naše soudy ve svých rozsudcích následují rozhodnutí Soudu (zda je následují se vším všudy, zda se od nich odlišují či zda je př́mo odmítají aplikovat). Pak se ptají, jaký je vliv rozhodnutí Soudu na vnitrostátní rozhodnutí. A v neposlední řadě zkoumají techniku odkazu na judikaturu Soudu.

Zde se mi hlavou honily dvě věci. První z nich je velmi specifická a vlastně i rozumím, proč se na ni autoři tolik nezaměřovali s ohledem na jejich obecnější cíle. Moc by mě ale zajímalo, jakou roli má judikatura Soudu přri úvahách NS a NSS na poli čl. 95 odst. 2 Ústavy, tj. při rozhodování, zda navrhnou ÚS, aby posoudil ústavnost jimi v konkrétní věci aplikované legislativy, kterou považují za nesouladnou s Úmluvou. Známý konkurzní nález, který zařadil (resp. ponechal) mezinárodní lidskoprávní smlouvy v referenčním rámci, pro který může ÚS shledat zákonné ustanovení za rozporné s ústavním pořádkem, ${ }^{27}$ totiž obecným soudům $\mathrm{v}$ tomto směru vystavěl tvrdé zátarasy př̀ práci s Úmluvou. Stále si ř́kám, jestli to tak opravdu mělo být a zda v souvislosti s euronovelou Ústavy nebylo úmyslem ústavodárce spíše soudům rozvázat ruce a dát jim možnost i s lidskoprávními smlouvami pracovat v souladu s nynějším textem čl. 10 Ústavy. Jednotlivcům v konkrétních věcech by to pomohlo. Ale chápu obecné systémové obavy podepřené důležitostí specializovaného koncentrovaného ústavního soudnictví.

$\mathrm{Na}$ to trochu navazuje druhé téma, které mě napadlo při čtení kapitoly o výzvách a možných nepresnostech výzkumu. Autoři zde vysvětlují, proč ze svého výzkumu vynechali nižší články naší soudní soustavy. Vychází z očekávání, že tyto soudy budou většinou

24 KOSA ̌r, 2020, op. cit., s. 90.

25 Ibid., s. 92.

26 Viz např. rozsudek NS ze dne 20. 5. 2009, sp. zn. 25 Cdo 1145/2009, kde se odkazuje na rozsudek Soudu „ze dne 29. brezna 2006 ve véci A. proti I., poprr. rozhodnutí ze dne 19. řjina 2004 ve véci D. proti S. "Pro pobavení doporučuji nap̌r. tento blogpost včetně diskuze, odkud jsem si tento př́klad od Jiřího Kmece vypůjčil. Dostupné z: https://bit.ly/3kQiPUs

27 Nález ÚS ze dne 25. 6. 2002, sp. zn. Pl. ÚS 36/01, část VII. 
následovat výklad Úmluvy zaujatý vrcholnými soudy. Plus uznávají, že získat potřebná data o jejich judikatuře by bylo prakticky nemožné.

Naprosto chápu jejich rozhodnutí. Ale překonání těchto překážek by do budoucna bylo skvělé, protože v některých oblastech se na nižších soudech pracuje s judikaturou Soudu při meritorním rozhodování konkrétních věcí dost možná více než na ÚS. Nejtypičtějším př́padem je ochrana osobnosti. Poté samozřejmě nemohu nezmínit některé oblasti správního soudnictví, např. azylové a cizinecké právo. S tím totiž souvisí jedna další proměnná: ony se mnohé kauzy, ve kterých obecný soud nižšího článku třeba i pracoval s judikaturou Soudu, vůbec nemusí k vrcholným brněnským soudům dostat. Ve správním soudnictví se např́klad kasační stížnost podává ,jen“ zhruba ve 45 \% věcí. ${ }^{28} \mathrm{~V}$ ostatních oblastech se také často stává to, co jsem zažil jako advokát, že zkrátka váš klient už nemá chut' a síly (či peníze) v kauze pokračovat. I př́padně vyhovující rozhodnutí jednoho z nejvyšších soudů či ÚS by mu totiž nic reálně nepřineslo, resp. by se tak mohlo stát v časovém horizontu, pro jehož délku se klient prostě raději vydá jinou nesoudní cestou, jak svůj problém řešit. Proto doufám, že někdo sebere vědeckou odvahu a pokusí se přeci jen zmapovat, jak se judikatuře Soudu daří u nižších článků naší justice. Dochází u nich k přímějšímu kontaktu s účastníky ř́zení. O ochranu jejich práv zaručených Úmluvou jde přitom v prvé řadě. Na jejich životy tak může mít aplikace judikatury Soudu v nižších patrech našeho soudnictví účinnější dopad. ${ }^{29}$

\section{Jak pracuje ÚS s judikaturou Soudu?}

Michal Bobek s Davidem Kosařem v roce 2010 označili ÚS za „šampióna používání Úmluvy “. ${ }^{30}$ Očekávali, že právě tento soud bude s judikaturou Soudu pracovat nejčastěji. Ve sledovaném období (1993-2015) však podle všeho ÚS odkázal na Soud jen ve 4,3 \% všech rozhodnutí. Toto číslo navíc zahrnuje i usnesení odmítající ústavní stížnost pro zjevnou neopodstatněnost, což může být zrádné. Obecně totiž zastávám názor, že z těchto usnesení vlastně neplyne nic jiného, než že se ÚS odmítl věcí plně meritorně zabývat. ÚS ani v usnesení, kterým odmítá ústavní stížnost pro zjevnou neopodstatněnost, nemusí hluboce analyzovat, zda došlo k porušení toho kterého základního práva. ${ }^{31}$

28 Viz např. slova současného předsedy NSS dostupná z: https://bit.ly/3jIPR7T

29 Pomyslným prvním výkopem je v tomto směru kniha Jana Kratochvíla Lidská práva v praxi obecných soudů, která loni vyšla v nakladatelství Leges.

30 KOSAŘ, 2020, op. cit., s. 169 s odkazem na BOBEK, Michal a David KOSAŘ. The Application of European Union Law and the Law of the European Convention of Human Rights in the Czech Republic and Slovakia: An Overview. In: MARTINICO, Giuseppe a Oreste POLLICINO (eds.). The National Judicial Treatment of the ECHR and EU Laws. A Comparative Constitutional Perspective. Groningen: Europa Law Publishing, 2010, s. 117-150.

31 Teoreticky by nemusel kromě odkazu na zákonný důvod odmítnutí ústavní stížnosti v usnesení analyzovat vůbec nic (\ 43 odst. 3 ZÚS). V praxi však ÚS tuto možnost nevyužívá. Alespoň krátké zdůvodnění odmítnutí ústavní stížnosti má význam i pro interní diskuze nad danou věcí mezi soudci a soudkyněmi ÚS, proto pak není důvodu, proč s ním neseznámit i účastníky řízení. 
Spíše by mě proto zajímalo, jak se s judikaturou Soudu pracuje v nálezech, obzvláště $\mathrm{v}$ jeho odůvodněních (nikoliv jen $\mathrm{v}$ narativní části nálezů či disentech). Nicméně jsem takové hlubší pojednání neobjevil. ${ }^{32}$ Přitom mám pocit, že právě tento aspekt věci má nejrelevantnější dopad, protože to je nálezová judikatura, kterou může ÚS realizovat reálné ,zzakořeněni““ judikatury Soudu a Úmluvy v našem právu.

Přes výše uvedené bych rád navázal na autory knihy ${ }^{33}$ a vyzdvihl důležitou roli, kterou má pro zacházení s judikaturou Soudu na ÚS analytický odbor ÚS. Jeho vedoucí L’ubomír Majerčík, který je ve funkci od roku 2013, ostatně sám na Soudu (i jinde v rámci Rady Evropy) několik let pracoval. Někteří pracovníci tohoto odboru měli taktéž pracovní zkušenost ze Soudu. A tento odbor dělá skvělou práci. Informuje celý ÚS o čerstvých rozsudcích Soudu proti České republice. Připravuje pravidelný bulletin, do kterého zahrnuje judikaturu Soudu. Pracují na analýzách ke konkrétním kauzám, v nichž se může judikatura Soudu objevit. A v neposlední řadě spolupracují s Kanceláří vládního zmocněnce pro zastupování ČR před Soudem na pravidelném zpravodaji o judikatuře Soudu za jednotlivá čtvrtletí.

Vůbec mě pak nepřekvapilo, že nejviditelnější v procentuálním zastoupení odkazů na judikaturu Soudu v jejich rozhodnutích jsou Kateřina Šimáčková a Eliška Wagnerová. ${ }^{34}$ Pro další výzkum by možná bylo zajímavé se zkusit podívat blíže i na to, jaké všechny štrasburské koncepty tyto dvě soudkyně přinesly do našeho práva. Jen namátkově si uvědomuji, že Eliška Wagnerová jako první aplikovala rozsudek Soering proti Spojenému království ${ }^{35}$ a zasadila se tak o prosazení zásady non-refoulement, podle níž nelze nikoho vydat do země, kde by mu hrozilo reálné riziko špatného zacházení nebo ohrožení života. ${ }^{36}$ Kateřině Šimáčkové pak určitě vděčíme za přenos práva na účinné vyšetřování. ${ }^{37}$ Do budoucna by proto mohlo být zajímavé se podívat na jednotlivé klasické koncepty dovozené Soudem, jak (resp. čí zásluhou) se objevily v naší judikatuře a jak se poté uchytily.

Meso úroveň zjištění o práci ÚS s judikaturou Soudu byla nemálo podnětná. Zejména jsem přemýšlel, zda se vůbec někdy stalo, aby ÚS výslovně a přiznaně odmítl následovat judikaturu Soudu (nemám tím na mysli pouhé odlišení věci od věci řešené Soudem). Pokud proto autoři tvrdí na základě výzkumu, že se tak ještě nestalo, není důvodu jim nevěřit. Ono by to ostatně bylo překvapivé, protože již zmíněný konkurzní nález znamená,

32 Jen na s. 175 se hovoří o tom, že většina odkazů je v usneseních a podíl odkazů v nálezech je „, fairly good“. K tomu autoři správně upozorňují, že v praxi nebývá úplně jasné, kde je hranice mezi řešením věci zamítavým nálezem a odmítavým usnesením. A také uznávají, že to může mít na výsledky dopad.

33 KOSA ̌́, 2020, op. cit., s. 170.

34 Ibid., s. 175.

35 Rozsudek ze dne 7. 7. 1989, ve věci Soering proti Spojenému kerálovství, č. 14038/88.

36 Srov. nález ÚS ze dne 15. 4. 2003, sp. zn. I. ÚS 752/02.

37 Srov. např. nález ÚS ze dne 2. 3. 2015, sp. zn. I. ÚS 1565/14. 
že ÚS učinil ze Soudu finálního interpreta části našeho ústavního pořádku (Úmluvy). ${ }^{38}$ Výše zmíněná věc ústavnosti právní úpravy změny pohlaví je proto obrovsky zajímavá i z tohoto pohledu. ÚS se bude muset znovu zabývat tím, jaká je jeho role při používání judikatury Soudu, jaká je role Soudu, př́padně zda se tyto role nemají změnit.

Je pak každopádně vidět, že autoři mají vlastní zkušenost s fungováním ÚS, kde působili (David Kosař) či dlouhodobě působí (Ladislav Vyhnánek). Neměl jsem totiž při čtení pocit, že by jejich rozbor zpo̊sobů práce s judikaturou Soudu a na to navazujících technik jejího používání neodpovídal tomu, jak jsem to sám coby asistent soudce ÚS cítil. V nálezech soudce Ludvíka Davida, pro nějž jsem pracoval, by bylo možné najít zřejmě všechny typy odkazů na judikaturu Soudu, at' už byly pouze ornamentální, podpůrné, nebo opravdu stěžejní pro danou věc. A bylo dechberoucí číst, co vše autoři na meso úrovni svého výzkumu zjistili.

Po dočtení mikero úrovně výzkumu a závěru, ve kterých jsem se opět hodně dozvěděl, se mi ovšem stále honilo hlavou, zda budeme moci v budoucnu konstatovat, jak tvrdí autoři, ${ }^{39}$ že ÚS je spojencem Soudu a že jeho př́stup k Soudu je poměrně pozitivní a práatelský. Bude si i nadále ÚS internalizovat judikaturu Soudu a snažit se jí vynucovat v co nejširším měřítku, jak autoři nyní ÚS popisujî? Bude stále správné rríkat, že je ÚS „ESLP-friendly“, protože se často a v dobré víře věnuje judikatuře Soudu? ${ }^{40}$ Věc řešená pod sp. zn. Pl. ÚS 2/20 a způsob, jakým se plénum ÚS vypořádá se stávající judikaturou Soudu, bude mít na odpovědi na tyto otázky obrovský dopad.

\section{Makro, meso i mikro závěry k soudnímu zacházení s judikaturou - včetně závěrů mých}

Ve finiši bych rád dodal opět jen několik nepřiliš urovnaných postřehů ke kapitole, která obsahuje zobecnění k práci s judikaturou Soudu na všech třech českých soudech. Zaznívá zde určitě důležitý postřeh, ${ }^{41}$ který se týká otázky, zda vůbec při tomto srovnávání ÚS, NS a NSS srovnáváme srovnatelné. NSS totiž jako jediný (až na věci rozhodované na krajských soudech samosoudci) nemá k dispozici určitý filtrační koncept, který mohou využít na ÚS a NS. At’ už jej nazýváme (ne)přijatelnost (NSS), (ne)př́pustnost (NS) či zjevná neopodstatněnost (ÚS), jde vždy - zjednodušeně řečeno - o to samé: zda soud konkrétní věc meritorně přezkoumá se vším všudy. Praxe odůvodňování rozhodnutí se proto liší, byt' si dokážu představit, že by NSS materiálně pracoval s konceptem přijatelnosti kasační stížnosti za podmínky přesahu vlastních zájmů stěžovatele, jak

38 Viz BOBEK, Michal. Evropská dimenze ochrany základních práv. In: WAGNEROVÁ, Eliška. Vojtěch ŠIMÍČEK, Tomáš LANGÁŠEK, Ivo POSPÍŠIL a kol. Listina základních práv a svobod. Komentár. Praha: Wolters Kluwer, 2012, s. 38.

39 KOSA $\check{R}, 2020$, op. cit., s. 191.

40 Ibid., s. 192.

41 Ibid., s. 199. 
jej vypracoval ve známém Ostapenko testu, ${ }^{42}$ i v dokumentu s hlavičkou rozsudku. ${ }^{43}$ Každopádně je procesní prostředí NSS oproti ÚS a NS zkrátka jiné, což je třeba mít při zobecňování na paměti.

$\mathrm{V}$ neposlední řadě je třeba přitakat autorům v tom, co lze vyčíst mezi rádky (a někdy i napřímo), že úroveň práce s judikaturou Soudu je „o lidech“. Velkou roli v tom majî nejen soudci samotní, ale i jejich asistenti či analytici a poradci soudu. Na všech třech soudech $\mathrm{v}$ poslední dekádě $\mathrm{v}$ těchto pozicích působilo a působí několik lidí, kteří bud' na Soudě pracovali, nebo tam byli alespoň na několikaměsíční stáži. Jde ostatně o jeden z cílů Rady Evropy. Např́klad na základních pracovních pozicích na Soudě tzv. B-právníků - totiž můžete pracovat maximálně čtyři roky. Je to záměr, abyste se poté vrátili do života práva ve vaší domovské zemi a tam šírili hodnoty Rady Evropy a principy plynoucí z judikatury Soudu.

Obecně myslím, že na práci s judikaturou Soudu má prímý dopad osvěta. Ta přichází hned z několika zdrojů. Sám Soud si dává (obzvláště po nástupu relativně mladého a progresivního Roberta Spana do funkce předsedy Soudu) záležet, aby byl vidět na sociálních sítích ${ }^{44}$ i jinde. Pro uživatele judikatury připravuje plno skvělých informačních materiálů, od tzv. factsheetů o konkrétních judikatorních tématech, ${ }^{45}$ přes přehledné tiskové zprávy k rozsudkům každé úterý a čtvrtek až po př́ručky o judikatuře k jednotlivým článkům Úmluvy, které nemají chybu. ${ }^{46}$ Sám Robert Spano pak za rok ve funkci vystoupil veřejně vícekrát než jeho předchůdci a tato jeho vystoupení - možná i díky pandemii - jsou zpětně dostupná on-line. ${ }^{47}$

Jsem také rád, že autoři v knize zmiňují práci Kanceláře vládního zmocněnce pro zastupování před Soudem. ${ }^{48}$ Díky ní také máme mnohé informace o judikatuře Soudu k dispozici na „stříbrném podnose“ Zpravodaje, vznikajícího ve spolupráci s analytickými odbory ÚS, NS a NSS a veřejného ochránce práv. ${ }^{49} \mathrm{~V}$ KVZ navíc spravují vyhledávač judikatury Soudu v češtině (eslp.justice.cz) a připravují nový lidskoprávní web, který opět soudům a soudcům zjednoduší přístup k judikatuře Soudu (i jiných lidskoprávních orgánů). Kromě toho všeho - snad to není tajné - tým okolo lidí z KVZ připravuje nový

42 Viz usnesení NSS ze dne 26. 4. 2006, č. j. 1 Azs 13/2006-39, č. 933/2006 Sb. NSS.

43 Tento př́stup už lze částečně v rozhodovací činnosti některých senátů vypozorovat, např. u 10. senátu NSS.

44 Viz např. jeho účet na Twitteru (https://twitter.com/ECHR_CEDH) a YouTube (https://www.youtube.com/user/EuropeanCourt).

45 Viz https://bit.ly/3oIXXRr

46 Viz https://bit.ly/3oJa9lf

47 Některá z nich jsou dostupná na předsednické stránce Roberta Spana z: https://bit.ly/2HSDysE; Vystoupení na konferencích souvisejících se 70. výročím Úmluvy si pak můžete pustit z: https://bit. ly/3mE7veI

48 Slangově nazývané „KVZ“.

49 Viz https://bit.ly/3jNOeWu 
komentář k Úmluvě, který by mohl navázat na úspěch komentáře kvarteta Jiř́ Kmec, David Kosař, Jan Kratochvíl a Michal Bobek $^{50}$ a nabídnout uživatelům judikatury Soudu její aktuálnější zpracování. Nelze vynechat ani zmíněného Jiřího Kmece a jeho pravidelné prŕspěvky do Soudních rozhledů nebo monitoring judikatury Soudu v časopisu Jurisprudence od Pavly Boučkové. A v neposlední řadě i naše právnické fakulty, kde už se Úmluva a judikatura Soudu učí v povinných předmětech.

Třeba právě i zde spočívá kouzlo toho, jak soudcưm a soudkyním našich vysokých soudů ukázat, že ten štrasburský kabát vůbec není špatný. Možná se obávají, že by jim $\mathrm{v}$ něm bylo prŕliš vedro. Tak tomu nutně nemusí být. Naopak by podle mě jejich rozsudky mohly vypadat mnohem víc chic, pokud by jim tento kabát oblékly. Stále se však po dočtení knihy nemohu zbavit dojmu, že je našim vrcholným soudům a zejména ÚS přeci jen lépe v oné košili Listiny a judikatury k ní.

Závěrem se mi krade na mysl ještě jedna poslední myšlenka: pomohl by Protokol č. 16 k Úmluvě? Dal vzniknout mechanismu, který v mnohém připomíná řízení o předběžné otázce u Soudního dvora. Vrcholné soudy by se podle něj mohly v konkrétních věcech obracet na Soud se žádostí o poradní posudek. Je na jinou diskuzi, zda by tuto pravomoc - pokud se vůbec ČR k tomuto nápadu přidá ${ }^{51}$ - měly mít ÚS, NS i NSS. Mohla by to každopádně být cesta, jak napomoci účinnějšímu prosazení judikatury Soudu v judikatuře českých vrcholných soudů. A třeba bychom po pár letech zjistili, že ten štrasburský kabát už tolik na věšáku nevisí.

50 KMEC, Jiří, David KOSAŘ, Jan KRATOCHVÍL a Michal BOBEK. Evropská úmluva o lidských právech. Komentár. 1. vyd. Praha: C. H. Beck, 2012, 1687 s.

51 Byt' už se v praxi několik žádostí o poradní posudek z jiných zemí objevilo. Třeba Slovensko se s účinností od 1. 4. $2020 \mathrm{k}$ tomuto mechanismu připojilo a na konci loňského roku ho již v praxi využilo (byt' neúspěšně, viz https://bit.ly/3vhWxQb). ČR bohužel Protokol č. 16 zatím ani nepodepsala. Blíže viz https://bit.ly/34Mph9K 